\title{
Pengaruh Pertumbuhan Perusahaan, Likuiditas, Profitabilitas, Non-Debt Tax Shield terhadap Utang Jangka Pendek
}

\author{
Lidya dan Indra Widjaja \\ Program Studi Manajemen Fakultas Ekonomi dan Bisnis \\ Universitas Tarumanagara, Jakarta \\ E-mail: lidyawei@gmail.com
}

\begin{abstract}
Abstrak: Penelitian ini memiliki tujuan untuk menguji pengaruh pertumbuhan perusahaan, likuiditas, profitabilitas, non-debt tax shield terhadap utang jangka pendek perusahaan sektor agrikultur pada laporan BEI tahun 2016-2019. Penelitian ini menggunakan 11 sampel perusahaan dengan purposive sampling. Data yang diambil dalam penelitian ini berasal dari situs resmi Bursa Efek Indonesia (BEI) yaitu idx.co.id . Data yang dikumpulkan kemudian diolah menggunakan EViews 10. Penelitian ini menunjukkan pertumbuhan perusahaan, nondebt tax shield tidak memiliki pengaruh yang signifikan terhadap utang jangka pendek. Dimana, profitabilitas memiliki pengaruh negatif terhadap utang jangka pendek. Likuiditas memiliki pengaruh negatif dan positif terhadap utang jangka pendek.
\end{abstract}

Kata Kunci: Pertumbuhan perusahaan, Likuiditas, Profitabilitas, Non-debt tax shield, Utang.

Abstract: This study aims to analyze the effect of company growth, liquidity, profitability, non-debt tax shield on short-term debt of agricultural sector companies in the 2016-2019 IDX report. This study obtained 11 sample companies with purposive sampling. The data taken in this study came from the official website of the Indonesia Stock Exchange (IDX), namely idx.co.id. The data collected is then processed using EViews 10. This study shows the company's growth, non-debt tax shield does not have a significant effect on short-term debt. Where, profitability has a negative influence on short-term debt. Liquidity has a negative and positive effect on short-term debt.

Keywords: Corporate growth, Liquidity, Profitability, Non-debt tax shield, Debt.

\section{LATAR BELAKANG}

Indonesia adalah negara agraris dimana sebagian besar penduduknya bermata pencaharian di sektor pertanian (agrikultur). Sektor agrikultur merupakan sektor yang dominan dan berpotensi besar dalam menyumbang perekonomian Indonesia. Perekonomian di Indonesia saat ini sedang lemah, sehingga banyak perusahaan yang terkena dampak, tidak terkecuali sektor agrikultur. Maka, upaya perusahaan untuk dapat bertahan adalah mencari dana tambahan agar menjaga kelangsungan perusahaannya di masa yang akan datang.

Dalam penelitian ini yang akan dibahas adalah keputusan dalam menggunakan utang, baik itu utang jangka pendek maupun utang jangka panjang. Perusahaan lebih banyak memilih utang sebagai sumber dana yang digunakan dalam membiayai operasi perusahaan daripada penggunaan modal perusahaan. Keuntungan dalam menggunakan utang yaitu bunga dalam membayar utang dapat digunakan untuk mengurangi pajak penghasilan.

Tingkat pertumbuhan perusahaan (growth) merupakan salah satu faktor yang dipertimbangkan dalam menentukan penggunaan utang. Menurut Hall dkk. (2004) yang terdapat dalam Ohman dan Yazdanfar $(2017$ :6) pecking order theory memprediksi hubungan positif antara pertumbuhan perusahaan dan rasio utang karena perusahaan dengan 
pertumbuhan tinggi biasanya membutuhkan modal besar untuk membiayai pertumbuhan mereka.

Keputusan penggunaan utang yang akan diambil perusahaan juga berkaitan dengan kemampuan perusahaan dalam mengembalikan utangnya. Akses untuk mendapatkan utang akan menjadi lebih besar apabila kemampuan perusahaan dalam mengembalikan utang juga semakin besar. Perusahaan perlu memperhatikan tingkat likuiditas beserta faktor-faktor yang mempengaruhinya sebab likuiditas merupakan dasar dalam menentukan kebijakan yang berlaku dalam perusahaan untuk dapat berkembang.

Profabilitas juga merupakan faktor yang mempengaruhi penggunaan utang dimana pendapatan direfleksikan untuk pendanaan investasi. Sesuai dengan Pecking order theory, perusahaan cenderung memilih pendanaan internal yang terdiri atas laba ditahan, aliran kas dan depresiasi daripada pendanaan yang berasal dari eksternal perusahaan. Ini menunjukkan hubungan negatif antara profitabilitas dan rasio utang menurut Myers dan Majluf (1984) dalam Ibrahim dan Lau (2019:80).

Kemudian, ada faktor lain yaitu non-debt tax shield, menurut Frank dan Goyal dkk. (2003) yang terdapat dalam Ohman dan Yazdanfar (2017:7) non-debt tax shield yang dianggap sebagai alternatif manfaat pajak dari penggunaan utang baik utang jangka pendek dan utang jangka panjang. Hubungan negatif antara leverage dan depresiasi sebagai proksi non-debt tax shield.

Berdasarkan uraian di atas, maka penelitian ini berjudul "Pengaruh pertumbuhan perusahaan , likuiditas, profitabilitas, non-debt tax shield Terhadap Utang Jangka Pendek."

\section{KAJIAN TEORI}

Gambaran Umum Teori. Penelitian ini menggunakan Pecking Order Theory dan Trade Off Theory. Pecking Order Theory menyatakan perusahaan akan lebih suka menggunakan dana internal terlebih dahulu jika memang tersedia untuk kegiatan operasional dan hanya akan menggunakan utang dan menerbitkan ekuitas baru sebagai upaya terakhir. Trade Off Theory menyatakan bahwa dengan adanya pajak pada perusahaan, akan menguntungkan bagi perusahaan untuk memegang lebih banyak utang daripada ekuitas karena perusahaan berpeluang mendapatkan pajak pengurangan dari bunga utang.

Utang jangka pendek atau yang disebut juga dengan current liability.Menurut Weygandt dkk. (2013:462) current liability adalah utang yang diharapkan perusahaan untuk membayar dalam satu tahun atau siklus operasi.

Utang jangka panjang merupakan utang yang jangka waktunya adalah panjang, umumnya lebih dari 10 tahun. Menurut sartono (2008 : 216) dalam Maulana dan Safa (2017:47) , utang jangka panjang atau long-term debt adalah suatu bentuk perjanjian antara peminjam dengan kreditur dimana kreditur bersedia memberikan pinjaman sejumlah tertentu dan peminjam bersedia untuk membayar secara periodik yang mencakup bunga dan pokok pinjaman.

Tingkat Pertumbuhan. Menurut Pakpahan (2010) dalam Rahayu (2019:982) tingkat pertumbuhan mengacu pada kemampuan perusahaan untuk mempertahankan posisinya dalam ekonomi dan pengembangan industri tempat perusahaan beroperasi. Perusahaan yang berkembang dengan baik cenderung menunjukkan pertumbuhan positif.

Rasio likuiditas. mengukur kemampuan bisnis untuk memenuhi pembayaran obligasi dengan membandingkan uang tunai dan hampir tunai dengan pembayaran obligasi. Jika cakupan yang terakhir oleh yang sebelumnya tidak cukup. Ini menunjukkan bahwa bisnis mungkin 
menghadapi kesulitan dalam memenuhi finansial obligasi langsungnya. Hal ini pada gilirannya dapat mempengaruhi operasi bisnis dan profitabilitas perusahaan.

Rasio profitabilitas. mengukur efisiensi perusahaan dalam mengoperasikan aset perusahaan. Banyak pemangku kepentingan seperti kreditor, investor, karyawan, manajemen dan yang lain tertarik pada posisi profitabilitas perusahaan. Jika perusahaan gagal memposting tingkat keuntungan yang memadai, itu akan mengurangi kas perusahaan dan mengarah ke masalah likuiditas.

\section{Hubungan Antara Variabel}

Pertumbuhan perusahaan (growth) menciptakan permintaan dana investasi. Sehingga, perusahaan dengan pertumbuhan tinggi akan mengambil lebih banyak utang daripada organisasi yang kurang berkinerja menurut Cassar dan Holmes (2003) dalam Benkraiem dan Gurau (2013:153).

Perusahaan yang memiliki likuiditas tinggi tentu akan memiliki rasio utang yang rendah. Sebab dengan adanya peningkatan ketersediaan sumber daya keuangan dalam hal likuiditas yang dihasilkan oleh laba ditahan memungkinkan perusahaan untuk tidak terlalu bergantung pada utang modal menurut De jong dkk. (2011) dalam Ohman dan Yazdanfar (2017:112).

Perusahaan yang menguntungkan cenderung dan lebih suka untuk menggunakan sumber internal (laba ditahan) sebagai prioritas dalam keputusan pembiayaan jika dibandingkan dengan perusahaan yang kurang menguntungkan, yang menghasilkan perusahaan harus meminjam lebih sedikit dibandingkan dengan perusahaan yang kurang menguntungkan.

Perusahaan dengan non-debt tax shield yang tinggi kecil kemungkinannya dalam meningkatkan utang ketika pendapatan perusahaan meningkat, karena perusahaan sudah menikmati manfaat pajak dari non-debt tax shield. Menurut DeAngelo dan Masulis (1980) dalam Cotei dan Farhat (2011:371) non-debt tax shield, depresiasi dan kredit pajak investasi dapat menggantikan pengurangan bunga.

\section{Penelitian Relevan}

Penelitian yang dilakukan oleh Proenca dkk. (2014) menyatakan pertumbuhan perusahaan (growth) dan non-debt tax shield memiliki pengaruh positif terhadap utang jangka pendek dan utang jangka panjang. Sedangkan pada profitabilitas memiliki pengaruh negatif terhadap utang jangka pendek dan utang jangka panjang. Dan likuiditas memiliki pengaruh negatif terhadap utang jangka pendek, dan pengaruh positif terhadap utang jangka panjang. Dalam penelitian yang dilakukan oleh Alipour dkk. (2015) menyatakan pertumbuhan perusahaan (growth), likuiditas, dan profitabilitas memiliki pengaruh negatif terhadap utang jangka pendek dan utang jangka panjang. Dalam hasil yang dilakukan oleh Ahsan dkk. (2016) menunjukkan bahwa pertumbuhan perusahaan (growth) dan non-debt tax shield tidak memiliki pengaruh yang signifikan terhadap utang jangka pendek. Sedangkan pada utang jangka panjang, pertumbuhan perusahaan (growth), likuiditas dan non-debt tax shield memiliki pengaruh positif. Likuiditas berpengaruh negatif terhadap utang jangka pendek. Profitabilitas memiliki pengaruh negatif terhadap utang jangka pendek dan utang jangka panjang. Hasil penelitian dari Nyeadi dkk. (2017) menemukan bahwa pertumbuhan perusahaan (growth) dan profitabilitas tidak memiliki pengaruh yang signifikan terhadap utang jangka pendek. Pertumbuhan perusahaan (growth) dan profitabilitas memiliki pengaruh negatif terhadap utang jangka panjang. Likuiditas memiliki pengaruh negatif terhadap utang jangka pendek dan pengaruh positif terhadap utang jangka panjang. Pada variabel non-debt tax shield ditemukan hubungan positif terhadap utang jangka pendek dan 
tidak memiliki pengaruh yang signifikan terhadap utang jangka panjang. Penelitian dari Mayuri dan Kengatharan (2019) menunjukkan bahwa pertumbuhan perusahaan (growth) dan non-debt tax shield tidak memiliki pengaruh yang signifikan terhadap utang jangka panjang. Likuiditas dan profitabilitas memiliki pengaruh negatif terhadap utang jangka panjang.

\section{Hipotesis}

H1 : Growth memiliki pengaruh terhadap utang jangka pendek.

H2 : Likuiditas memiliki pengaruh terhadap utang jangka pendek.

H3 : Profitabilitas memiliki pengaruh terhadap utang jangka pendek.

H4 : Non-debt tax shield memiliki pengaruh terhadap utang jangka pendek.

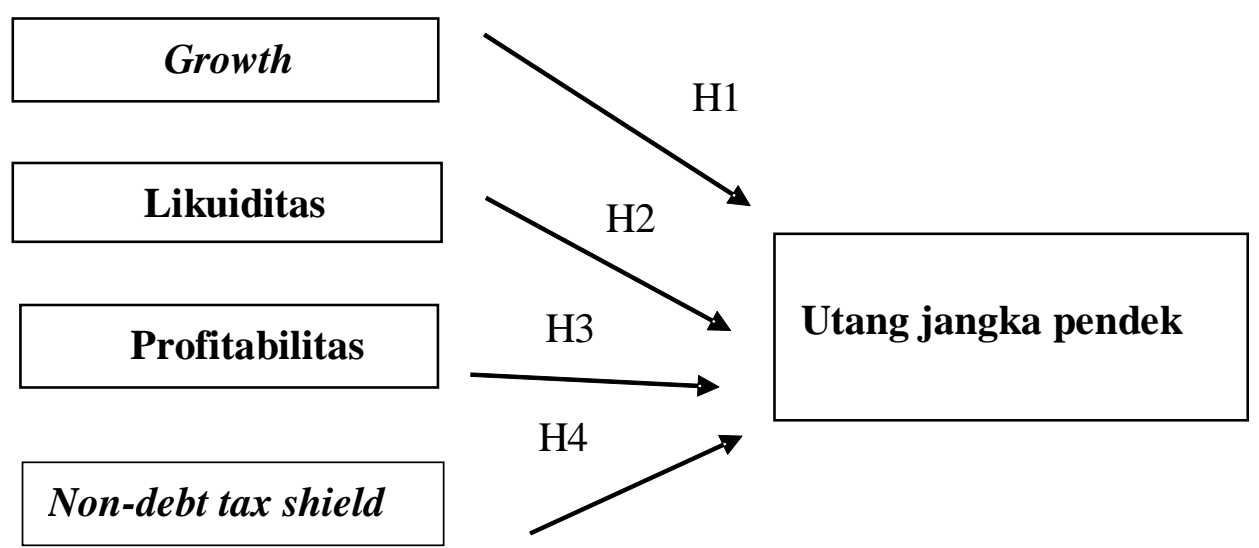

Gambar 1. Kerangka Pemikiran

\section{METODOLOGI}

Penelitian ini menggunakan metode kuantitatif, dengan desain penelitian bersifat kausalitas, untuk meneliti kemungkinan adanya hubungan sebab-akibat antar variabel. Model data yang digunakan merupakan data panel, yaitu data gabungan antara data runtut waktu (time series) dengan data sesi silang (cross section). Perusahaan sektor agrikultur yang terdaftar pada BEI tahun 2016-2019 merupakan subjek dari penelitian ini. Adapun sumber data yang diambil oleh peneliti berasal dari website resmi BEI yaitu www.idx.co.id. Dengan menggunakan teknik purposive sampling, maka sampel yang diambil dalam penelitian ini menjadi 11 perusahaan dari 22 perusahaan sektor agrikultur.Peneliti menggunakan Microsoft excel untuk mengumpulkan data, setelah itu mengolah data menggunakan aplikasi EViews 10.

Utang jangka pendek: STD $=\frac{\text { short term debt }}{\text { total asset }}$

Utang jangka panjang: $L T D=\frac{\text { long term debt }}{\text { total asset }}$

Pertumbuhan perusahaan (growth): Growth $=\frac{\text { total asse }_{t}-\text { total asset }_{t-1}}{\text { total asset }_{t-1}}$

Likuiditas: $C R=\frac{\text { current asset }}{\text { eurrent liabilities }}$

Profitabilitas: $R O A=\frac{\text { earning after tax }}{\text { total asset }}$

Non-debt tax shield: NDTS $=\frac{\text { depreciation }}{\text { total asset }}$ 


\section{HASIL UJI STATISTIK}

\section{Hasil Uji Multikolinearitas}

Tabel 1. Hasil Uji Multikolinearitas

\begin{tabular}{crrrr} 
& GROWTH & CR & \multicolumn{1}{c}{ ROA } & \multicolumn{1}{c}{ NDTS } \\
\hline \hline GROWTH & 1.000000 & 0.308578 & 0.374833 & 0.071374 \\
CR & 0.308578 & 1.000000 & 0.452777 & 0.036314 \\
ROA & 0.374833 & 0.452777 & 1.000000 & -0.111466 \\
NDTS & 0.071374 & 0.036314 & -0.111466 & 1.000000
\end{tabular}

Sumber : Hasil olah data EViews 10

Berdasarkan hasil olah data diatas dengan uji multikolinearitas, dapat dilihat bahwa variabel ROA memiliki hubungan negatif sebesar 0,111466 terhadap variabel NDTS. Semua variabel independen dalam penelitian ini yaitu GROWTH, CR, ROA, dan NDTS tidak memiliki korelasi dengan angka yang melebihi 0,8. Sehingga, dapat disimpulkan bahwa tidak terdapat masalah multikolinearitas dalam penelitian ini.

\section{Hasil Uji Chow}

Tabel 2. Hasil Uji Chow Utang Jangka Pendek

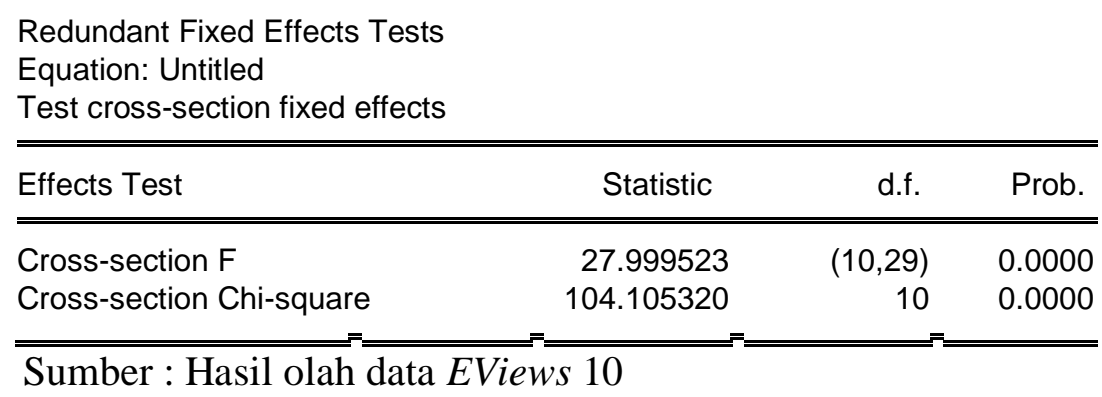

Tabel hasil uji diatas menunjukkan bahwa cross-section $\mathrm{F}$ dan cross-section Chi-square memiliki nilai probabilitas sebesar 0.0000. Dimana nilai 0.0000 lebih kecil dari tingkat signifikansi sebesar 0,05 yang berarti $\mathrm{H}_{0}$ ditolak. Maka dengan itu, dapat disimpulkan dari uji chow ini adalah fixed effect model merupakan model yang terbaik untuk variabel dependen utang jangka pendek.

\section{Hasil Uji Hausman}

Tabel 3. Hasil Uji Hausman Utang Jangka Pendek

\begin{tabular}{|c|c|c|c|}
\hline Test Summary & $\begin{array}{l}\text { Chi-Sq. } \\
\text { Statistic }\end{array}$ & Chi-Sq. d.f. & Prob. \\
\hline Cross-section random & 6.430928 & 4 & 0.1692 \\
\hline
\end{tabular}

Sumber : Hasil olah data EViews 10 
Tabel hasil uji diatas menunjukkan bahwa cross-section random memiliki nilai probabilitas sebesar 0.1692. Dimana nilai 0.1692 lebih besar dari tingkat signifikansi sebesar 0,05 yang berarti $\mathrm{H}_{0}$ tidak ditolak. Maka dengan itu, dapat disimpulkan dari uji hausman ini adalah random effect model merupakan model yang terbaik untuk variabel dependen utang jangka pendek.

\section{Hasil Uji Lagrange Multiplier}

Tabel 4. Hasil Uji Lagrange Multiplier Utang Jangka Pendek

\begin{tabular}{|c|c|c|c|}
\hline $\begin{array}{l}\text { Null (no rand. effect) } \\
\text { Alternative }\end{array}$ & $\begin{array}{l}\text { Cross-section } \\
\text { One-sided }\end{array}$ & $\begin{array}{l}\text { Period } \\
\text { One-sided }\end{array}$ & Both \\
\hline Breusch-Pagan & $\begin{array}{l}30.85071 \\
(0.0000)\end{array}$ & $\begin{array}{l}0.859381 \\
(0.3539)\end{array}$ & $\begin{array}{l}31.71009 \\
(0.0000)\end{array}$ \\
\hline Honda & $\begin{array}{l}5.554342 \\
(0.0000)\end{array}$ & $\begin{array}{c}-0.927028 \\
(0.8230)\end{array}$ & $\begin{array}{l}3.272005 \\
(0.0005)\end{array}$ \\
\hline King-Wu & $\begin{array}{l}5.554342 \\
(0.0000)\end{array}$ & $\begin{array}{c}-0.927028 \\
(0.8230)\end{array}$ & $\begin{array}{l}1.855162 \\
(0.0318)\end{array}$ \\
\hline GHM & $\begin{array}{l}-- \\
--\end{array}$ & $\begin{array}{l}-- \\
--\end{array}$ & $\begin{array}{l}30.85071 \\
(0.0000)\end{array}$ \\
\hline
\end{tabular}

Sumber : Hasil olah data EViews 10

Tabel hasil uji diatas menunjukkan bahwa Breusch-pagan memiliki nilai cross-section one-sided sebesar 0.0000. Dimana nilai 0.0000 lebih kecil dari tingkat signifikansi sebesar 0,05 yang berarti $\mathrm{H}_{0}$ ditolak. Maka dengan itu, dapat disimpulkan dari uji lagrange multiplier ini adalah random effect model merupakan model yang terbaik untuk variabel dependen utang jangka pendek.

\section{Hasil Analisis Regresi Linier Berganda}

Tabel 5. Hasil Analisis Regresi Linier Berganda Utang Jangka Pendek

Dependent Variable: STD

Method: Panel EGLS (Cross-section random effects)

Date: 06/16/20 Time: 02:20

Sample: 20162019

Periods included: 4

Cross-sections included: 11

Total panel (balanced) observations: 44

Swamy and Arora estimator of component variances

\begin{tabular}{crrrr}
\hline \hline Variable & Coefficient & Std. Error & t-Statistic & Prob. \\
\hline \hline C & 0.224554 & 0.075586 & 2.970821 & 0.0051 \\
GROWTH & 0.083261 & 0.071598 & 1.162902 & 0.2519 \\
CR & -0.029782 & 0.013780 & -2.161268 & 0.0369 \\
ROA & -0.600166 & 0.140976 & -4.257229 & 0.0001 \\
NDTS & 0.456890 & 0.250266 & 1.825619 & 0.0756 \\
\hline \hline
\end{tabular}


Lidya dan Indra: Pengaruh Pertumbuhan Perusahaan, Likuiditas, Profitabilitas...

\begin{tabular}{llll} 
& Effects Specification & S.D. & Rho \\
\hline \hline $\begin{array}{l}\text { Cross-section random } \\
\text { Idiosyncratic random }\end{array}$ & & 0.196479 & 0.8854 \\
& & 0.070693 & 0.1146 \\
\hline \hline & Weighted Statistics & \\
\hline \hline R-squared & 0.516788 & Mean dependent var & 0.041894 \\
Adjusted R-squared & 0.467228 & S.D. dependent var & 0.099824 \\
S.E. of regression & 0.072863 & Sum squared resid & 0.207051 \\
F-statistic & 10.42747 & Durbin-Watson stat & 0.972092 \\
Prob(F-statistic) & 0.000008 & & \\
\hline \hline & Unweighted Statistics & \\
\hline \hline R-squared & 0.331433 & Mean dependent var & 0.236610 \\
Sum squared resid & 2.059768 & Durbin-Watson stat & 0.097716 \\
\hline \hline
\end{tabular}

Sumber : Hasil olah data EViews 10

Dilihat dari persamaan analisis regresi berganda di atas, maka dapat diketahui bahwa nilai konstantanya adalah 0.224554 . Artinya yaitu nilai utang jangka pendek (STD) memiliki nilai sebesar 0.224554 apabila pertumbuhan perusahaan (GROWTH), likuiditas (CR), profitabilitas (ROA), non-debt tax shield (NDTS) dianggap memiliki nilai 0. Untuk hasil uji t, diketahui bahwa variabel GROWTH dan NDTS yang tidak signifikan pada penelitian ini karena nilai probabilitas lebih besar dari 0,05 . Untuk hasil uji F, $F$-statistic memiliki nilai sebesar 0.000008 , yang berarti bahwa nilai $F$-statistic tersebut lebih kecil dari 0,05 . Sehingga dapat disimpulkan bahwa semua variabel independen memiliki pengaruh stimulan terhadap variabel utang jangka pendek sebagai variabel dependen pada penelitian ini secara signifikan. Untuk hasil uji koefisien determinasi, Adjusted $R$-squared memiliki nilai sebesar 0.467228 atau $46.72 \%$, yang berarti bahwa variabel GROWTH, CR, ROA, NDTS dapat menjelaskan variabel STD sebesar $46.72 \%$. Variabel selain variabel independen pada penelitian ini dapat menjelaskan sisanya yaitu sebesar $53,28 \%$.

\section{DISKUSI}

Hipotesis yang diterima dalam penelitian ini adalah $\mathrm{H} 2$, dan $\mathrm{H} 3$. Likuiditas dan Profitabilitas memiliki pengaruh negatif signifikan terhadap utang jangka pendek. Hasil ini didukung oleh penelitian dari Proenca dkk. (2014:189) dan Alipour dkk. (2015:73) Hasil ini konsisten dengan pecking order theory yang menyatakan bahwa perusahaan akan lebih suka menggunakan dana internal terlebih dahulu jika tersedia untuk kegiatan bisnis mereka. Pertumbuhan perusahan (growth) dan non-debt tax shield tidak memiliki pengaruh yang signifikan terhadap utang jangka pendek Hasil ini didukung oleh berbagai penelitian yaitu Benkraiem dan Gurau (2013:158), Mayuri dan Kengatharan (2019:51) dan Ahsan dkk. (2016:373).

\section{PENUTUP}

Likuiditas dan profitabilitas memiliki pengaruh negatif signifikan terhadap utang jangka pendek pada perusahaan sektor agrikultur yang terdaftar pada Bursa Efek Indonesia tahun 2016-2019. Pertumbuhan perusahaan (growth) dan non-debt tax shield tidak memiliki pengaruh yang signifikan terhadap utang jangka pendek pada perusahaan sektor agrikultur 
yang terdaftar pada Bursa Efek Indonesia tahun 2016-2019. Saran yang dapat diberikan adalah sebaiknya perusahaan sektor agrikultur memperhatikan likuiditas dan profitabilitas dalam menggunakan utang, sebab likuiditas berpengaruh signifikan terhadap utang jangka pendek. Dimana profitabilitas berpengaruh signifikan terhadap utang jangka pendek.Peneliti menyarankan untuk penelitian selanjutnya agar ditambahkan subjek penelitian, memperjanjang periode dalam penelitian, serta manambahkan variabel independen yang diteliti.

\section{DAFTAR PUSTAKA}

Ahsan, T., Wang, M. \& Qureshi, M. A. (2016). Firm, Industry, and Country Level Determinants of Capital Structure: Evidence from Pakistan. South Asian Journal of Global Business Research. 5(3), 362-384.

Alipour, M., Mohammadi, M. F. S. \& Derakhshan, H. (2015). Determinants of capital structure: an empirical study of firms in Iran. International Journal of Law and Management. 57(1), 53-83.

BEI (2020). Bursa Efek Indonesia. Retrieved June 2020, from www.idx.co.id.

Benkraiem, R. \& Gurau, C. (2013). How Do Corporate Characteristics Affect Capital Structure Decisions of French SMEs? International Journal of Entrepreneurial Behaviour \& Research. 19(2), 149-164.

Cotei, C. \& Farhat, J. (2011). An Application of The Two-stage Bivariate Probit-Tobit Model to Corporate Financing Decisions. Review of Quantitative Finance and Accounting. 37(3), 363-380.

Ibrahim, H. \& Lau, T. (2019). The Determinants of Financial Leverage for Surviving Listed Companies in Malaysia. International Journal of Business and Society. 20(1), 75-94.

Maulana, Z. \& Safa, A. F. (2017). Pengaruh Hutang Jangka Pendek dan Hutang Jangka Panjang Terhadap Profitabilitas Pada PT. Bank Mandari Tbk. Jurnal Penelitian Ekonomi dan Akuntansi (JENSI). 1(1), 44-48.

Mayuri, T. \& Kengatharan, L. (2019). Determinants of Capital Structure: Evidence from Listed Manufacturing Companies in Sri Lanka. SCMS Journal of Indian Management. 16(1), 43-56.

Nyeadi, J. D., Banyen, K. T. \& Mbawuni, J. (2017). Determinants of Capital Structure of Listed Firms in Ghana: Empirical Evidence Using a Dynamic System Gmm.

Ohman, P. \& Yazdanfar, D. (2017). Short- and long- term debt determinants in Swedish SMEs. Review of Accounting and Finance. 16(1), 106-124.

Proenca, P., Laureano R. M. S. \& Laureano L. M. S. (2014). Determinants of Capital Structure and The 2008 Financial Crisis: Evidence From Portuguese SMEs. Procedia - Social and Behavioral Sciences. 150, 182-191.

Rahayu, S. M. (2019). Mediation Effects Financial Performance Toward Influences of Corporate Growth and Assets Utilization. International Journal of Productivity and Performance Management. 68(5), 981-996.

Weygandt, J. J., Kimmel P. D. \& Kieso, D. E. (2013). Financial Accounting IFRS Edition $2 e$. New Jersey: Johny Wiley \& Sons Inc. 